\title{
A publisher, a bobbin-boy and the Society
}

\section{Presidential address to the Medical Society for the Study of Venereal Diseases, 28 April, 1995 at The Royal College of Physicians of} London

\author{
J S Bingham
}

\section{Introduction}

The Medical Society for the Study of Venereal Diseases was founded in 1922 and the first Annual General Meeting was held on 31 July that year at the Royal Society of Medicine. Its membership was drawn, originally, from doctors of varying backgrounds in Medicine. For instance, there would have been those in practice in the new municipal clinics created by the Venereal Diseases Act of 1917 (over 200 in 1922). There were bacteriologists and pathologists, dermatologists, gynaecologists, physicians with an interest, often financial, in the venereal diseases and there were surgeons.

\section{The London Lock Hospital}

Many of you will know that, at one time, the surgical fraternity saw the treatment of the venereal diseases as very much its own preserve. Indeed, the old Lock Hospitals were dominated by surgeons. These hospitals stemmed from the lazar-houses in the Middle Ages, when they sheltered those who were loosely diagnosed as having leprosy. With the advent of the syphilis epidemic in 1495 the

Figure 1 Lt. Col. $\not$. Fohnston Abraham CBE DSO MD FRCS.

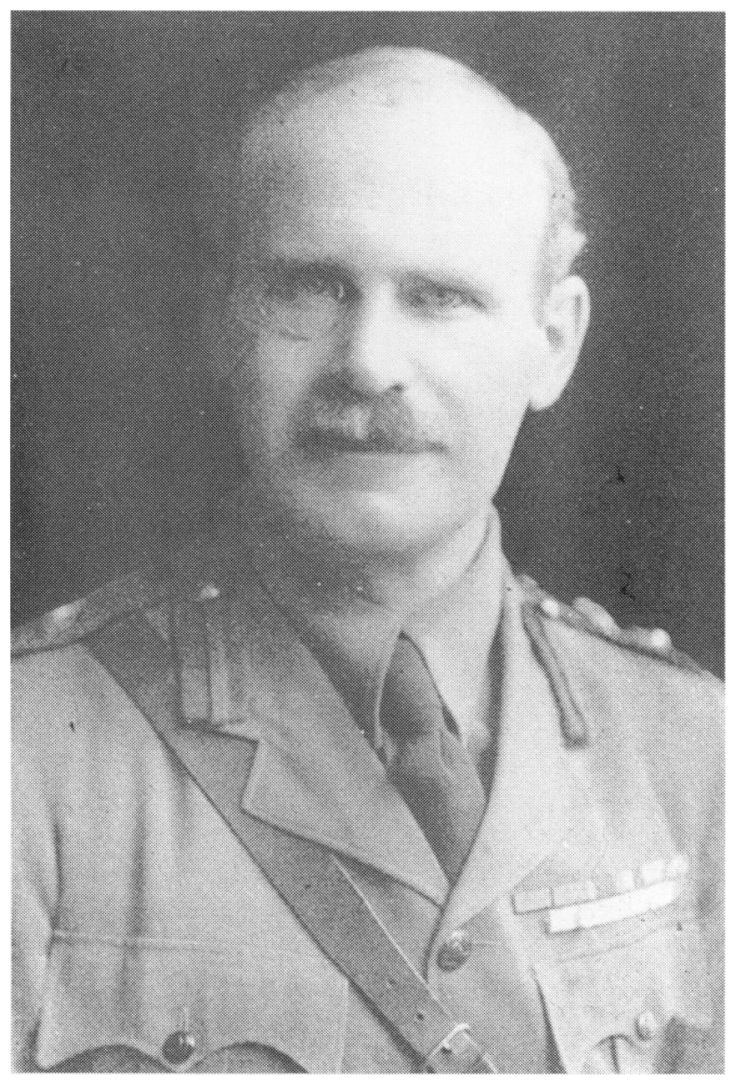

ease and in this way the name of Lock (derive from Les Loques or Les Lock-the rags with which they cleaned themselves before admis sion) became associated with venereal disease There were 11 Locks in London when this happened but their number had dwindled tô two by 1720 and, as they were old and costles to maintain, these closed too. Williari Blomfield, a surgeon at St George's Hospitât at Hyde Park Corner, realised that there was still a need and opened a Lock Hospital just off Grosvenor Place, in 1746. The lease was not renewed by the Grosvenor Estate and 8 new Lock was built at Westbourne Green, and opened in 1842. Later, finding out-patienf would not go so far from the centre of London, another site was bought in Deaq Street, Soho, in 1869. There were thus two hospitals with the same title under the same management.

James Johnston Abraham (fig 1)

I would like to tell you about one of the suc geons who worked at the Lock Hospitals partly because he was an Ulsterman like myself, but also because he had an interestin? life and saw and was part of the advances i our field in the early part of this century. He was almost certainly a member of this Societe although he never held office. He addressed the Society twice: on the 28 May 1926 on Marriage and gonorrhoea and on 24 April 1948 on The History of the Treatment of Syphilis.

James Johnston Abraham was born in Coleraine in County Antrim, Norther Ireland. The second of six children, his fathe was a strict Methodist, a lay preacher and $\cong$ successful tea merchant. His mother's family were of a strict Presbyterian background and of farming stock. One of the great loves of his life was to be books, literature and writing and he developed this interest as a small boy in the extensive library at his grandmother's farm.

Early days $\mathrm{He}$ was educated at the Roy Coleraine Academical Institution. $\mathrm{He}$ reaf Medicine at Trinity College, Dublin. He hagी had a classical education and was more inter ested in the Arts than in Medicine. He attended lectures by Professor Dowden Professor of English Literature, won all the English prizes and agonised whether or not to abandon the medical course. On the Professor's advice he persisted with medicine on the grounds that it was a more certain living, but he never abandoned his love of literature and writing. Dowden told him "literature 
is a very bad crutch, but a very good walking stick". In fact he was paraphrasing Charles Lamb.

At Trinity he had a splendid time, indulged successfully in a little amateur journalism in the Dublin press, and got an excellent grounding in medicine. Infectious diseases were still prevalent and he became experienced with tetanus, typhoid, smallpox and even typhus. Abraham was a final year medical student at the time of the Boer War and, along with many of his contemporaries, could not wait to qualify in order to go off to South Africa. He was too late, in the event.

Wondering what to do after qualification, he, along with many other Irishmen decided to apply for the Indian Medical Service. He was unfit for that because of his eye-sight. He was offered the post of Physician to the King of Siam. The King always employed three Western doctors, a Frenchman, a German and an Englishman; the Englishman had always been an Irishman but Abraham declined that particular post despite his desire to go to the East. Instead he did a spell as Resident in Colles Ward of Steeven's Hospital in Dublin, named after Abraham Colles of Colles' fracture and Colles' law fame. He developed his interest in venereal diseases there.

$\mathrm{He}$ moved to London and found employment as a house surgeon at the West London Hospital under a man called Keetley, who was one of two who founded the Royal Postgraduate Medical School in West London. He had an interesting time at the hospital and diagnosed the first case of smallpox at the beginning of the Kensington and Hammersmith epidemic of 1902 . After a number of other hospital posts and some time in general practice he eventually came back to London and decided to study to become a surgeon. Keetley took him back into the West London and he assisted him in rewriting his textbook of surgery as well as ghosting another book for a different surgeon on Diseases of the Throat and Nose.

He was exhilarated at passing the Primary part of the Fellowship at the first attempt but his pleasure was shortlived. He began to feel very lethargic, lost weight and developed an irritating cough. Coming from Ireland, where tuberculosis was prevalent, he immediately consulted a physician at the Brompton Hospital who auscultated his chest, found crepitations at the apices and thereby made the diagnosis clinically. He roomed with a pathologist who confirmed the diagnosis, microbiologically. The physician advised six months rest.

Ship's surgeon and his first book For an impecunious young man this was bad news as he could not afford to take the time off. He had agreed, after graduation, that he would not be a financial burden on his father who could well have afforded to help him out. Indeed, he had offered to buy him a practice had he not pursued the surgical route. The pathologist roommate came up with the idea of a sea voyage and he enlisted for a six month spell as a ship's surgeon on a 10,000 ton cargo ship which carried no passengers, sailing from Birkenhead.

He had such a splendid time that he became somewhat of a bore about it upon his return and his pathologist friend persuaded him to write a book about his experiences. He did, and hawked it around nine publishers; they all turned it down. One day, when having afternoon tea in the Staff Room of St Peter's Hospital, Henrietta Street, Covent Garden, he looked out of the window. Across the road he saw the offices of Chapman \& Hall, Dickens' publishers. He sent them the manuscript and the Managing Director, Arthur Waugh (Evelyn's father) accepted it. He had originally called it The Voyage of the Clytemestra, the name of his ship, but Waugh changed the title to The Surgeon's $\log ^{1}$ and it became a bestseller on both sides of the Atlantic and was still selling steadily in the late 1950 s, particularly in its Penguin form. It is a beautifully written descriptive travelogue, not dissimilar in style to that of Eric Newby.

It must have been a wonderful and restful experience which was what he needed. With only the crew to look after he had little medical work to do and was able to relax on deck in the tropics and go ashore in the ports. They sailed non-stop to Port Said, traversed the Suez Canal and then crossed the Indian Ocean to Penang. They sailed down the Malacca Strait to Singapore. From Singapore they sailed to Japan and visited Nagasaki, Moji and then by the Inland Sea to Kobe and on to Yokohama (and Tokyo). From there they sailed to the Dutch East Indies and thence home via Marseilles.

His second book The success of the book tempted him to give up medicine but he remembered Dowling's advice and carried on with surgery. Arthur Waugh asked him for another book and he resurrected a manuscript he had written some years earlier-Waugh thought there was a book in it. It was based on hospital life in Dublin and concerned medical students, young doctors and nurses. He called it Concerning FitzGerald, but Arthur Waugh told him that he had not the slightest idea of how to invent a selling title and renamed it The Night Nurse. It also became a best seller and was thought to be very wicked being banned by the Matrons of all London Hospitals except Guy's.

Abraham at the Lock Upon his return from the East, he looked around for a job and found one as a Resident Medical Officer at the London Lock Hospital for Women in the Harrow Road, thereby beginning an association that was to last over 40 years. This was where he confirmed his interest in the venereal diseases, particularly syphilis. He was there, in 1905, after Schaudinn and Hoffmann had discovered Treponema pallidum. This was not visualised using dark field microscopy, as nowadays, but rather by staining with Indian ink. The treponemes could be seen with their characteristic movement against the dark background of the Indian ink. 
The following year the Wassermann reaction was written up and this brought Abraham some prominence. A girl aged 8 years was admitted to the Lock Hospital with early infectious syphilis. It was thought that a soldier, home on leave, who was staying in her parents' house had infected her. It was suspected that the soldier was an adherent to the belief that, if you can make contact with a virgin, the disease will transfer to her and leave you cured. Abraham was asked to see the soldier in Brixton Prison and made medical history by doing a Wassermann test on him which proved to be positive and he was convicted; the first case of its kind. He became very popular with pathologists who wanted access to the livers of dead syphilitic babies in order to produce the reagents for the test. This brought him much popularity and many free dinners until it was discovered that an extract of ox heart was just as good. In the light of all this experience he wrote an MD thesis entitled Recent Advances in the Diagnosis and Treatment of Syphilis which was accepted by Trinity College.

He finally passed the second part of the Fellowship Examination. He took rooms in Harley Street thereafter, was elected on to the staff of the Princess Beatrice Hospital (later St Mary Abbott's) in Earl's Court and also obtained a post as a Surgical Registrar at the Lock Hospital in the Harrow Road.

The First World War Upon the outbreak of the First World War he tried to enlist but was turned away. The war was expected to be over by Christmas and the War Office and the Royal Army Medical Corps (RAMC) was looking for newly qualified men and not more mature sorts like Abraham. He contacted Sir Frederick Treves, of the Elephantman fame. Treves had been in the South African War at the turn of the century and had been one of those responsible for establishing the RAMC. $\mathrm{He}$ was recruiting for the British Red Cross and Abraham volunteered to go with a surgical unit to Serbia. You will remember that, after the murder of the Archduke Franz Ferdinand in Sarajevo, the Central Powers (Germany and Austria-Hungary) threatened Serbia. The Czar and Russia stood firmly behind their Slavic brothers in the Balkans, not dissimilar to the situation today, and the Great War began. "The Schwabs", the AustroHungarians, invaded Serbia and initially the Serbs were routed and fell back in retreat. The Government moved from the capital, Belgrade, to Nish in Southern Serbia. The Serbs appealed for assistance and it was to answer this call that a number of British Red Cross units were sent to the Balkans.

Serbia They sailed to Piraeus via Malta and thence to Salonika, which had only been freed from the Ottoman Empire eighteen months earlier. Abraham's unit consisted of six surgeons with two orderlies each, led by a slow Canadian Scotsman surgeon called McLaren. They entrained at Salonika to travel north to put themselves at the disposal of the Serbian authorities and had thought that they were going to Nish but, only got as far as Skoplje (Uskub). They had been sent out by Sir Frederick Treves as an Advanced Dressing Station but the Serbs wanted them to run a hospital; in fact they ran three. The Serbs were in full retreat at that stage and thousands of wounded, including prisoners of war (POWs) were pouring back into the town. Abraham's unit treated 70,000 men in two and a half months of which two thousand were able to get back to the fighting lines. They had one thousand beds but always had 1,500 inpatients. There were no nurses so they used the Austrian POWs. Disease was rampant: scarletina, diphtheria, typhoid and smallpox. Most of the staff got relapsing fever too.

The Serbs eventually halted the Austrian advance and the workload eased. Unfortunately typhus was found in the POW camp and gradually spread everywhere. Abraham had had previous experience in Ireland and made the original diagnosis of the epidemic to come. It was said that over 1 million people were infected and there were at least 120,000 deaths in a population of less than half that of London. The Serbian authorities did nothing to prevent the spread but Abraham went to see the Serbian Prime Minister, Mr Pasitch, who asked for help. The RAMC sent out a Colonel Hunter. He was given full powers; he stopped all trains, he stopped all Army leave and disinfected the trains and clothing. The epidemic was brought under control in one month. Some of Abraham's staff died from it. $\mathrm{He}$ and others smeared their bodies with a mixture of vaseline and paraffin oil to keep the lice off them and they came through unscathed.

Survivors of the unit were exhausted after six months in Serbia, when their contract was up. Indeed, Abraham had lost four stones in weight and could not eat. They returned to the UK where he reported to Sir Frederick Treves. Information about the typhus epidemic had been censored by the Serbs as they feared the Austrians might attack again if it was realised that they were so defenceless. The Director General of the RAMC, Sir Alfred Keogh, was informed by Treves and then Kitchener's Military Secretary. It had been planned to send a British expeditionary force to Serbia but with the information about the epidemic now available it was considered too much of a risk. If this force had gone, it is possible that the Bulgars might not have come in on the German side. The Germans would not then have been able to go to the aid of the Turks, Gallipoli would have been unnecessary and the campaigns in Mesopotamia and Palestine radically altered-another example of how disease can change the course of history.

The Middle East In fact Abraham spent most of his war in the Middle East. One month after returning to London he joined the RAMC as a Lieutenant. He recuperated and was sent to Egypt as a surgeon to a Stationary Hospital near Ismalia in the Canal Zone. The 
Commanding Officer was a lazy regular soldier and Abraham became 2IC. He really ran the unit and the Director of Medical Services (DMS), an Irishman called General Maher, got on well with him. Abraham's native common sense impressed him to such an extent that he was promoted above many senior regular officers to become Assistant Director of Medical Services (ADMS) for the Palestine Lines of Communication, on General Allenby's staff. He had seen the medical difficulties after the first two battles of Gaza which the Turks had won and his suggestions as to how the problems could be remedied were the reason for his promotion. ${ }^{2}$

The Sinai Desert is an extremely difficult area for military operations. Allenby's predecessor, General Sir Archibald Murray, had built a railway across the desert and had constructed a pipe line to carry water. For the third battle, Gaza was bombarded as a diversion and the real attack went in on Beersheba. When he visited the old Turkish Hospital there the main medicine available was a huge supply of " 606 ". There were 4,400 sick and wounded to be dealt with at this battle but the Gaza-Beersheba line was broken leaving the way clear for the advance on Jerusalem. The Turks had left Jerusalem in a frightful mess and Abraham was responsible for clearing it up. Malaria in the wadis had to be treated and this was accomplished by a Major P Manson$\mathrm{Bahr}$, who was on the staff.

Abraham performed splendidly behind Allenby's army and had considerable influence with the general himself. It was a huge job providing the medical and surgical care for an advancing army extending eventually as far as Damascus and Beirut. The wounded were brought back on camels and then evacuated further by ambulance train across the Sinai to the Canal and Egypt.

He had to cope with the 1918-19 influenza pandemic which badly affected the Army. $\mathrm{He}$ supplied medical stores to King Feisal's army, operating in conjunction with T E Lawrence. He met him and treated him for "a minor problem". He described him as "a little man with the delicate frame of a girl, with startlingly intense blue eyes in a thin, very tanned face. He looked about 20, wore his uniform carelessly - a 2nd Lieutenant's badge on one loose shoulder-strap and a Colonel's on the other-and went about in carpet slippers". He was awarded the DSO for his efforts and was appointed CBE after hostilities ceased, upon his return to the UK.

Return to London Back in London Abraham returned to the Princess Beatrice Hospital and was appointed as a surgeon to the staff at the London Lock Hospital at the Harrow Road. He steadily built up a busy surgical practice in Harley Street, although Jonathan Hutchinson, who had been one of his mentors at the London Hospital, had told him before the First World War that his practice had been ruined because of his interest in venereal diseases, especially syphilis.

He married Lilian Angela, daughter of Dr
Alexander Francis, in 1920 and they had one daughter.

More books Work at his two hospitals was voluntary, and unpaid. However, it occupied his time as his practice was building up. $\mathrm{He}$ started writing again and had his Balkan Log $^{3}$ on his Serbian experiences published in 1922 . $\mathrm{He}$ wrote Leaders in the British Medical Journal and in the Lancet. He taught medical students from St Mary's Hospital at Harrow Road and also students at Charing Cross Hospital. He published a book, Lectures on Gonorrhoea in Women ${ }^{4}$ in 1924. In 1930 he wrote a book on Cottage Hospitals in conjunction with an architect.

In 1933 his book Lettsom, his Life and Times was published, to much critical acclaim, receiving two complementary pages in the Times Literary Review. ${ }^{5}$ Abraham always felt that this was his best literary work. Then in 1935, along with H. Wynne Finch, he undertook a translation of Fracastoro's “De Morbo Gallicus" from the Latin into English. It had actually been done several hundred years earlier but this was an up to date translation.

In 1939 Ninety-nine Wimpole Street-A Doctors Digressions appeared-really a collection of essays and he produced a number of books, based on articles in the Sunday Graphic under the pseudonym of James Harpole. He chose this name because he lived at 22 Queen Anne Street, in the section between Harley Street and Wimpole Street. The books were called Leaves from a Surgeon's Casebook, The White-coated Army, Behind the Surgeon's Mask and A Surgeon's Heritage.

A clubbable man All this hard work took its toll on him and in 1935 he had surgery for a duodenal ulcer. Although continuing his hospital appointments and his consulting practice he gave up major surgery thereafter and probably concentrated on venereal diseases. He was a clubbable man. He became a member of the Savage Club before the First World War and was elected to the Athenaeum in 1920 . He joined the Garrick Club later on in his life. $\mathrm{He}$ kept in touch with the literary world at the Savage and got to know great scientists and men of the moment at the Athenaeum. His autobiography is littered with well known names-Kipling, George Bernard Shaw, T.S. Eliot, D. H. Lawrence, Max Beerbohm, Arnold Bennett, H. G. Wells, Lutyens the architect, and John Tweed the sculptor. $\mathrm{He}$ also knew Lord Rutherford, Lord Moynihan, Sir Alexander Fleming who worked with him at the Lock Hospital and Sir Almoth Wright, a fellow Trinity man, to mention but a few. He dined with them regularly as well as with politicians such as Ramsey MacDonald, Lloyd George, whom he once treated, and Clement Atlee.

He was particularly pleased when, in 1934, a film was made of his book, The Night Nurse. It was filmed in Dublin, in County Mayo and at Ealing Studios but, because of cuts made by the Censor, he did not feel that it was a great success. In America it was 
Figure 2 The publisher, Mr. F. Fohnston Abraham.

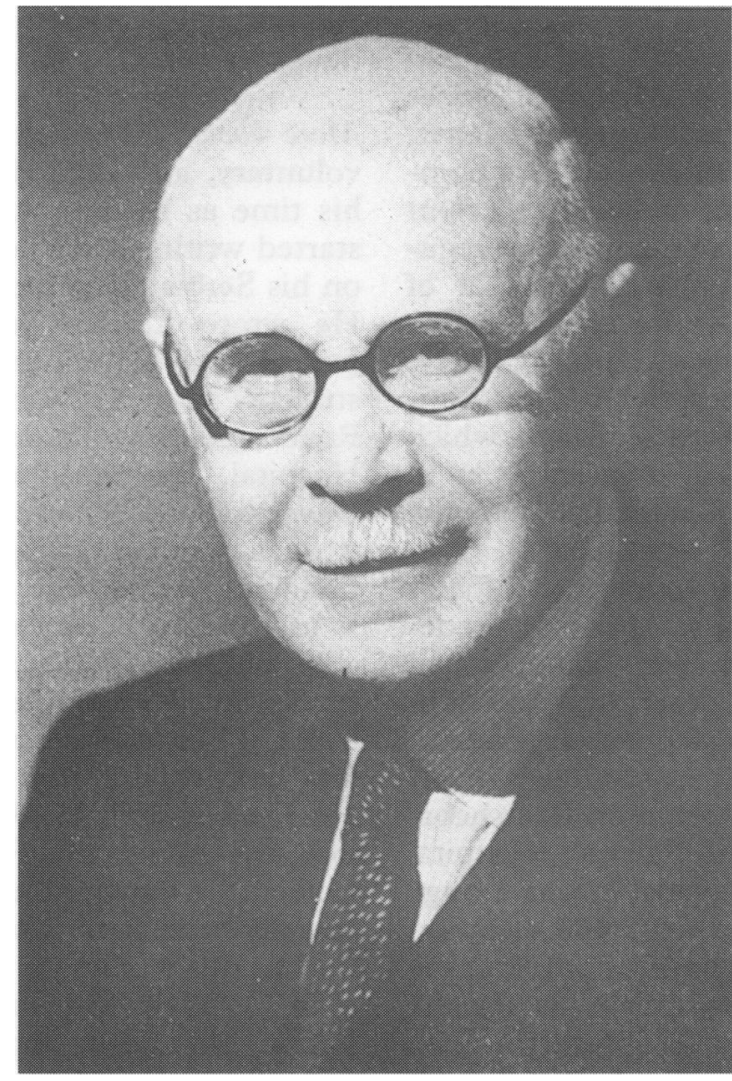

shown as Nora O'Neal and in Europe as Irish Hearts.

The publisher and orator One of those whom he met at the Savage Club was Charles Evans of the publishers William Heinemann Limited. Abraham felt that one of their authors, in a novel, had represented hospital life unrealistically - the nurses had a dance in an operating theatre. He told Evans that what the firm needed was a medical adviser. A week later they offered him the post-one afternoon a fortnight (fig 2). The work built up and he joined the Board and from 1942 became the Chairman and Managing Director of William Heinemann, Medical Books Ltd. Amongst many other titles he published a Life of Paul Ehrlich of "606" fame.

During the Second World War he broadcast with the BBC, as James Harpole, giving medical advice to the nation. In 1943 he delivered the Thomas Vicary Lecture at the Royal College of Surgeons on The Early History of Syphilis and in 1946 the Annual Oration before the Medical Society of London on The Two Fothergills. To the same Society he gave the Lloyd Roberts Lecture in 1948. Lloyd Roberts had described himself as a general specialist with a leaning towards women. He was, in fact, a gynaecologist. When asked once by Sir John Bland-Sutton to define gynaecology, he replied: anything in a woman that is operable or lucrative and many gynaecologists thereafter have had comfortable lives applying that dictum. Trinity College, Dublin, conferred on him the Honorary Degree of Litt D, in 1946. In 1948 he was appointed a Commander of the Order of St John of Jerusalem. He was a founder member of the Faculty of the History of Medicine and Pharmacy at the Society of Apothecaries of London.

\section{Death of a hospital}

The Lock Hospital at Harrow Road had been commandeered by the military during the Waf but, when it was vacated afterwards, it was decided not to re-occupy it and it was turnece into administrative offices for a section of the North West Metropolitan Regional HospitaR Board. All activities there were transferred to\%. the West End branch in Dean Street. It was then decided to close even this hospital anf Abraham fought a valiant rearguard action tof save the hospital, at least for a while. He triect to amalgamate it with The Middlesex Hospita尼 but they declined. With the advent of penit cillin and other antibiotics, however, the Board felt that a special VD hospital was nof required and eventually moved the West Enct Hospital for Nervous Diseases into the build ing in Dean Street, in 1948. All the records there were transferred to the Royal College of Surgeons in Lincoln's Inn Fields, an interest $-\bar{c}$ ing source for study if anyone had the time.

James Johnston Abraham was a polymatho $\mathrm{He}$ had a breadth of education that few doctors have, today. He had been a successfup surgeon and venereologist. He had been के distinguished soldier, author and publisher $\mathrm{He}$ was clubbable with a wide variety of friends outside medicine and he was clearlye an excellent conversationalist and bor viveur. His death on 9 August 1963, one week short of his 87 th birthday, in a ways marked the end of an era; the end of the generalist surgeon with an interest in venerea diseases.

\section{Brave new world}

For in 1948, with the formation of the National Health Service, the speciality of venereology was established within itThereafter, the membership of the Societ gradually became predominantly from this narrower background, and that has remained the case ever since. I would now like to telP you, rather more briefly, about a product this new age. In doing so, I hope to be able to describe the life and achievements of anothef interesting man who made his mark on oun field. Like Abraham he was clubbable, with â wide circle of acquaintances and he had an interesting war. Many of the members here more mature in years, will remember him welf but I hope that his story will be of interest to the younger members who do not. $\mathrm{He}$ was my old chief, mentor and friend, Dr Rober Duncan Catterall.

\section{Robert Duncan Catterall-early days}

Catterall was born at Bramhall in Cheshire or 9 July, 1918, into a well-to-do cotton manus facturing family. $\mathrm{He}$ was educated at Ottershaw School, in Surrey, and upon leaving school he entered his father's cotton manufacturing company and hoped to emulate him and become a Captain of Industry. He began by setting out to learn the business from the bottom and therefore started work as a bob- 
bin-boy at the factory. He was a fine ball player and represented Cheshire at both tennis and cricket during those years.

Unfortunately, the Second World War intervened to halt his steady progress. He hated violence and thought that it was evil but he was not a conscientious objector. He was unwilling to just wait for something to happen, or to wait to be conscripted and in September 1939 along with a friend, he reported for training with a Friend's (Quaker) Field Ambulance Unit, formed with the object of service abroad.

The Winter War Resultant on the Ribbentrop-Molotov Pact of the summer of 1939, and the fall of Poland, the Red Army occupied the Baltic States and invaded Finland across the Karelian Isthmus on 1 December 1939. The Finns resisted firmly, and initially successfully, and held the Russians on the Mannerheim Line. Early in 1940, 60 members of the Field Ambulance with 20 ambulances left Newcastle for Norway and Finland. It was a harsh war with mobile Finnish snow troops outfighting the Red Army. Eventually, with the use of air power and the sheer weight of numbers against them, the Finns had to retreat. The Field Ambulance was operating on the Laduga Front and transported the wounded, mainly at night, because of the heavy bombing during the day. In March, unsupported by the rest of the world, the Finns capitulated and reached an accommodation with the Russians that prevented the occupation of the whole country. The Field Ambulance helped to transport some of the thousands who fled from their homes rather than live in the territory ceded to Russia-it was often very harrowing work. In April, Germany invaded Norway, and the Ambulance made its way out of Finland, across Sweden, and linked up with British and French Forces which had landed at the town

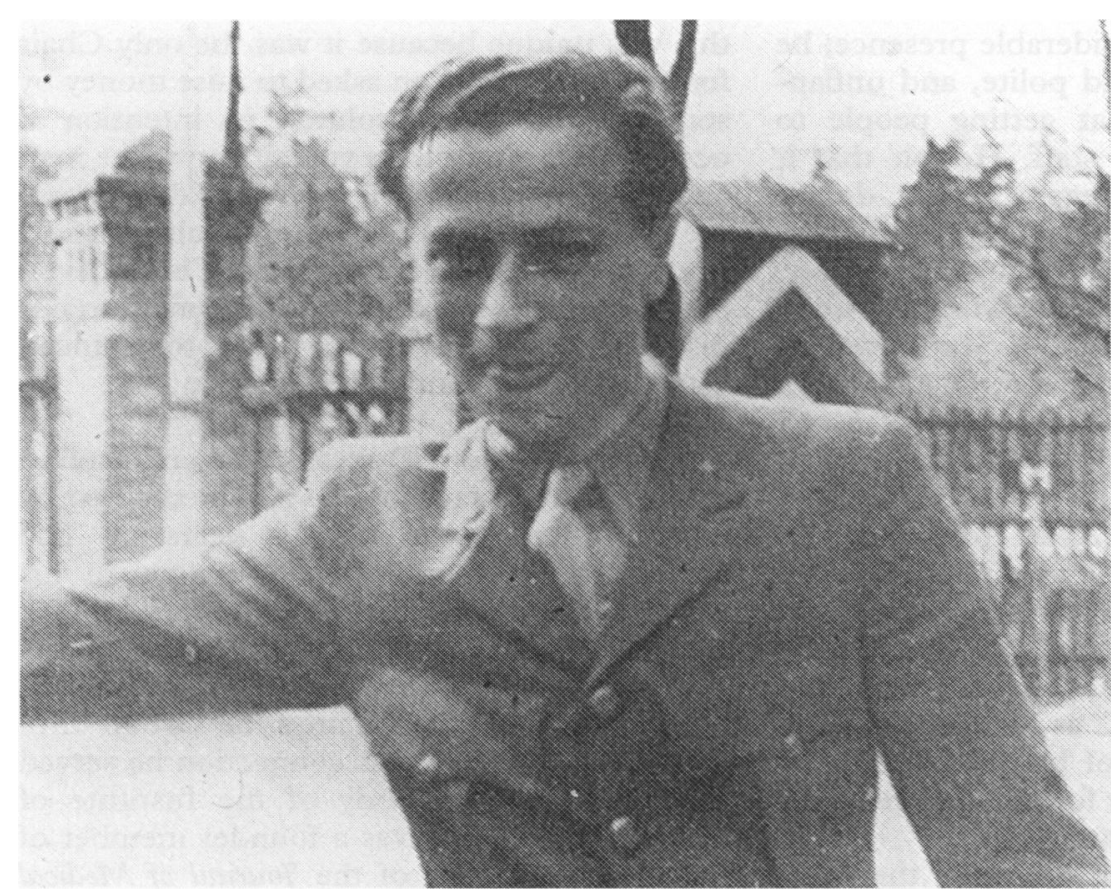

Figure 3 Duncan Catterall on the morning of his release from prisoner of war camp. of Namsos. Their stay at Namsos was brief as the town was destroyed from the air, but half of the Unit escaped back to England and the rest, including Catterall, had to make a dash across the mountains to neutral Sweden, in order to avoid capture.

Escape and capture in Greece The group was benevolently interned in Stockholm for some months. The only way out was through Russia and eventually they managed to fly to Moscow and then by train to Odessa, across the Black Sea to Istanbul, and by rail and road to Cairo and Alexandria. The Unit served with the 8th Army in the Western Desert but was sent with the British Expeditionary Force to Greece. As the Army retreated south it was obvious that evacuation from Greece was inevitable.

Duncan Catterall was with a group that reached the port of Kalamata, where they helped to carry some of the wounded on board transports. He could have remained on board one of these ships and sailed to safety but he chose to stay with the large number of wounded lying in the Town Hall of Kalamata. They were marched to Salonika where they were part of a huge prisoner of war camp holding several thousand men. Someone wrote of this place: "It was blazing hot. Prison life produced a list of horrors which reached a frightening crescendo: the guards shot at a doctor, two medical orderlies were shot at close range and a hand grenade was thrown into the latrines". The party was split up into a number of groups at that stage and a friend who had been with Duncan since Finland wrote: "Parting from Duncan with whom I had shared so many jokes and escapades, was hard-a more civilised being you could not wish to meet-his dress was always immaculate and he never seemed ruffled by the appalling series of misfortunes. I will never forget that he stayed behind to wait for us in Greece when he could so easily have gone".

Catterall's party was transported north through Yugoslavia by train and, in the Alps, he escaped but was, unfortunately, recaptured attempting to cross the Swiss border.

Four years followed in a prisoner of war camp in Germany. He learnt to speak French fluently from a fellow French prisoner, Albert Roques, who subsequently became his Best Man. He assisted the Australian Surgeon in the camp, Leslie le Souef, and this made him determined to take up medicine after the war. He spoke German, in addition to French, and was able to use his skills as an interpreter to maintain peace and to stop fighting between angry prisoners and their jailers. Albert Roques said that he could not remember ever seeing him lose his temper nor hear him swear and he was always patient, polite and cheerful. These were qualities that he maintained throughout the rest of his life.

The Medical Student Upon return to the UK (fig 3), he spent a year at Queen Mary's College studying physics, chemistry and biology in order to gain entrance to a Medical School. In 1946, at the age of 28 years, he entered the London Hospital Medical College 
and graduated in 1951. There are apocryphal tales of the Rolls Royce he possessed as a student; in fact he had a very elderly Wolseley but it was, in the words of his wife, "terribly clean". He roomed with his cousin, Dorothy Brierley, a well-meaning middle class lady who devoted her life to running the Docklands Settlement for down and outs in the East End. It was there that Duncan lived throughout his student days. He helped her in her work but he found time to enjoy sport again and he represented the United Medical Schools at tennis and hockey.

Venereology A post in the Whitechapel Clinic with Mr Ambrose King persuaded him to pursue venereology as a career. Like many other trainees of that era, he spent a year with Earle Moore at the famous Clinic L, at the Johns Hopkins Hospital, in Baltimore. Al Capone was a patient there at the time, having been removed from Alcatraz with general paralysis of the insane. Whilst he had treatment with penicillin, fever therapy was still in vogue and he received a good dose of malarial parasites, without benefit.

Upon his return to the UK, there was a shortage of consultant posts and he was stuck for some time as an SHMO at St Thomas' Hospital, before being appointed as consultant venereologist to the General Infirmary at Leeds, in 1959. He did sessions at Bradford too, and he used to say that he saw the Aldermen of Leeds in Bradford and the Aldermen of Bradford in Leeds. In 1964 he was appointed to The Middlesex Hospital, in London. It had never had a venereologist on the staff before and he was not, initially, made very welcome. The hospital had identified a speculative office block in Charlotte Street and took it over in the building stages. It was, I suppose, the first of the modern venereology clinics-and it was above ground. He called it James Pringle House, after an Irish dermatologist at the hospital in the early part of the century.

He was a man of considerable presence; he was always courteous and polite, and unflappable. He was skilled at getting people to talk-both patients and staff. He felt that it was an enormous privilege to be a doctor and he volubly deplored the decision, made in the mid-1970s, to pay doctors overtime. "Medicine", he wrote in a letter with his wife to the British Medical Journal, "is a contemplative liberal profession and must be a way of life rather than a means of earning a living on an hourly basis".

Contributions to the field Apart from establishing one of the first new style clinics, Duncan Catterall made a number of major contributions to our specialty. Along with Drs Claude Nicol and Jimmy Fluker he realised that genitourinary medicine, as a name, better described the activities of his field. Together they lobbied successfully for the change at the Royal College of Physicians.

He was one of those who, in the early 1970s, established a postgraduate course for sexually transmitted diseases at the British Postgraduate Medical Federation. Associated with it, but not linked, is the Diploma in Venereology (now Genito-Urinary Medicine) examination at the Society of Apothecaries of London, which he was largely responsible for establishing.

The first Chair $\mathrm{He}$ recognised the need to create an academic base for our specialty and he fought hard to establish the first Chair in Genito-Urinary Medicine at The Middlesex Hospital Medical School. The School used to be a fairly conservative place, in many senses, and his wish to establish an academic department was strenuously opposed. It was said that the School could not afford another Chair and there was serious doubt as to whether or not there would be applicants with the academic ability to fill it, within the subject of venereology. I doubt if there can be a better testament to Duncan's skill as a diplomat than that he was able to persuade the school to change its mind and allow a department to be established. But he had to accept some pretty stringent conditions if he was to do that. There were to be no running expenses of the department chargeable to the School, no salaries were to be chargeable to the School and the department would not be eligible for the Equipment Grant which was given to Heads of Department.

Most people would have run for cover given those sorts of conditions but Duncan did not. He set about raising the money to endow the Chair. He started by holding dinners inviting such dignitaries as the recently retired Prime Minister, Harold Wilson and Sir James Goldsmith. You will not be surprised to hear that they did not raise very much money for him. Finally, he hired a fundraiser, Duncan Guthrie after whom the Chair is now named, who had previous experience of raising money to establish University chairs. The sum required was finally realised and the Chair was established in 1979. Duncan Guthrie felt that this was unique because it was the only Chair for which he had been asked to raise money by someone who had absolutely no intention of occupying it himself. As you all know, the man appointed was Professor Michael Adler. There are now four other Chairs in our subject and a number of senior lecturer posts. These developments have been of enormous benefit to our discipline and are entirely due to Duncan Catterall's vision and determination.

The suave teacher Duncan was an inspired teacher and the fact that he is remembered by most students over his 19 years at The Middlesex Hospital bears testament to his skills. He was a Founder Member of the London Medical Group and was on its Consultative Council from almost the beginning. From 1973 he Chaired the Group until he retired. Through this connection he served on the Governing Body of the Institute of Medical Ethics and was a founder member of the Editorial Board of the Fournal of Medical Ethics. 
At a Thanksgiving for his life and work, in 1993, one of the speakers suggested that the fact that he looked like a cardiologist must have helped to improve the image of our speciality. I have no doubt that this is true. He was above fashion and his sartorial elegance in his department and on the wards in his welltailored suits, always with turn-ups when they were not necessarily de rigeur, detached collars and gleaming shoes was greatly admired by his patients, as much as by his staff. Quite how much attention he paid to his dress I did not realise until one day I picked up the telephone in his secretary's office. The caller said that he was from Gieves and Hawkes and he asked me to inform Dr Catterall that his new underwear had been made and was awaiting collection.

The servant and traveller $\mathrm{He}$ was a loyal servant of this Society having been its President and Honorary Secretary and he sat, ex offico, on Council for many years in his capacity as our representative on the UEMS and as Adviser to the Ministry of Health. He served on numerous World Health Organization working parties, where his linguistic abilities were most helpful (fig 4).

In his last years, before retirement, he travelled extensively overseas. As President of the International Union Against the Venereal Diseases and Treponematoses he established an African branch and visited West and East Africa on a number of occasions. He went to Puerto Rico and visited India on several occasions as well as Malaysia and Singapore. He visited Australia and New Zealand several times giving advice to their respective governments. He made many friends on these visits and greatly enhanced the reputation of our

Figure 4 Dr. R. D. Catterall CBE FRCP. specialty abroad. Many of those whom he met overseas visited him in London and he used to entertain them at his club, the East India and Devonshire. He was awarded the Thomas Parran Award of the American Venereal Diseases Association in 1982.

He found time to return to Kalamata in Greece, where he had been captured by the Germans, and to the prisoner of war camp at Elsterhorst where he had been interned for four years. He also managed to revisit Finland.

Like James Johnston Abraham he was a great conversationalist. He enjoyed good food and was a considerable connoisseur of wine. Indeed, in 1980, he became a Vigneron d'Honneur du Beaujolais. He retired from the National Health Service in 1983. Just before his retirement, in the Birthday Honours of that year he was appointed CBE. He thought that this was an unbelievable honour for doing a job that he loved. Unfortunately, his retirement was marred by debilitating neurological illness which he bore with great fortitude. He died on 5 May, 1993, at home in Chelsea.

\section{The Society-taking stock}

Our Society will be 75 years old in two years time and the time is ripe to review our situation and take stock. We now have approximately 650 members, more than ever before, with around 120 of them overseas; so we have an international dimension too. We have substantial cash reserves in the bank and we have a secretariat based at the Royal Society of Medicine. The bulk of our members are genitourinary physicians although we have attracted small numbers of members from allied disciplines.

We are a learned society although much of the time of Council has been bogged down in medico-political matters in recent years. In $\mathrm{Dr}$ Willy Harris' presidency, the Council advised the establishment of an appropriate body to deal with this important area and the Association for Genitourinary Medicine (AGUM) was born and now addresses these issues effectively. This has given the Society an opportunity to concentrate more on scientific and educational matters. In my presidency we have established an Education Committee whose remit has been to plan the scientific programme for our meetings, to act as the hanging committee for papers submitted for the Spring Meeting and to consider and foster undergraduate education in our field. You will all have had a report on that. The Committee has also considered Continuing Medical Education (CME) and has tried to put together, and fund, a three-year rolling programme. This is by no means established yet but, hopefully, the Society will be able to deliver a programme, jointly with AGUM.

But the format of our meetings has not changed in the 20 years that I have been a member of the Society. We now have six Ordinary General Meetings (OGM's) instead of five, and the Spring Meeting has been extended by half a day to two days. While we invite speakers from other disciplines, as a group we tend to operate in isolation from 
other fields. In 1994 we did have a joint meeting with the Public Health doctors (PHMEG) at the Guild Hall in the City, which was successful. I feel that we should organise more meetings like that.

The Society-the way forward?

One way of doing this might be to consider having special interest groups within the Society. The British Association of Dermatologists and the British Thoracic Society have done this for years and it has always struck me that it might be a possibility for us. Many of you may know that a meeting will take place at Cambridge, in September, when doctors from various disciplines involved in the care of patients with HIV infection and AIDS will meet. The principle players in this are not genitourinary physicians and the Council feels that this sort of grouping could usefully come under our umbrella as an HIV interest group. It would have the advantage of including other major contributors in this area and would result in a national multi-disciplinary group taking us back to the rather wider constituency that existed when the Society was established.

Once you take this idea on board it would be a natural progression to think of other areas of interest: a virus group concerning viruses other than HIV, a group for the bacterial sexually transmitted diseases (STDs) - not dissimilar to the STD Study Group, and a group dealing with matters around Sexual Healthrape, contraception and psycho-sexual matters, but there could be others. I suspect that these groups could focus the scientific agenda for the Society and could operate their own meetings in addition to or, instead of, the OGMs, perhaps as fora or workshops. Indeed, with proper academic leadership, they might prove a better basis for focused collaborative research in our field, than the British Co-operative Clinical Group.

Governance of the Society is another area of concern. The Council has grown gradually larger over the years and now has over 20 people sitting on it. It is somewhat dominated by London and this has irritated many of those outside London, for years. We now have the
Education Committee, which has been appointed but not elected. This has irritated some members of Council although it is, nominally, a sub-committee of the Council. Do we need so many people governing the Society, and who should they be?

I have mentioned, earlier, the establishment of academe in our field. This has been an important development and, although academics are well represented on the Education Committee, they have been poorly represented, numerically, on Council. They have much to contribute to a learned society and certainly should be taking the academic lead, although not to the total exclusion of others. In my view, our organisation needs streamlining; ways must be found to focus our interests while broadening our base. We shall probably require a smaller governing group and preferably one that represents a range of interests, perhaps partly derived from interest groups.

Finally, the Society's name might be reconsidered. This did happen a decade ago when Dr Brian Evans was President. Council did approve a change of name, to the Society of Genitourinary Medicine, but the motion to do this was defeated at the Annual General Meeting in 1985. The Medical Society for the Study of Venereal Diseases does have a certain ring to it but, is it the most appropriate name nowadays?

What I have mentioned are simply some ideas as to how we might move forward and I hope that they will stimulate a lively debate. Indeed, the Council has appointed a small working party to consider the matter. All of these issues will need careful consideration as we move into the last 25 years of our first century. We are in a fascinating and evolving area of Medicine and I believe that, with the correct decisions, the Society's future is assured.

1 Abraham JJ. The Surgeon's Log: Impressions of the Far East. London, Chapman and Hall, 1911 .

2 Abraham J. Surgeon's fourney. London, Heinemann, 1957. 3 Abraham J. My Balkan Log. London, Chapman and Hall, 1921

4 Abraham JJ. Lectures on Gonorrhoea in Women and Children. London, Heinemann, 1924

5 Abraham JJ. Lettsom: his Life, Times, Friends and Descendants. London, Heinemann, 1933. 